\title{
Medium-Sized Cities: Polycentric Strategies vs the Dynamics of Metropolitan Area Growth
}

\author{
Luis Alfonso Escudero Gómez ${ }^{*}$ and Jose Somoza Medina² \\ ${ }^{1}$ Department of Geography, University of Castilla-La Mancha, Spain \\ ${ }^{2}$ Department of Geography and Geology, University of León, Spain
}

\begin{abstract}
The European territorial strategy known as the European Spatial Development Perspective (ESDP) has as its main thrust the development of a multi-centred and balanced urban system. European, national, and regional investments have been concentrating on the formation of polycentric urban regions, or city clusters, in which medium-sized cities, acting as nodes, would have a major role. In this paper, an overall development index is applied to Spanish medium-sized cities. This uses economic, social, environmental, and territorial parameters to discover what their real growth trends are and what results have been achieved by policies for multi-centred development. In this way, it can be demonstrated that the efforts to create polycentric urban regions yield poorer results in development terms than the dynamic trend towards growth of metropolitan areas and those related to tourist activity on the coast. Factors driving this, related to the process of urbanisation in Spain over the last few decades, continue to override institutional land-use guidelines.
\end{abstract}

Keywords: Medium city, land-use strategies, polycentricism, metropolitanisation, Spain.

\section{MEDIUM-SIZED CITIES}

In Spain many things have changed in the last ten years, while others, which it was supposed would inevitably have to evolve, have remained unaltered. The country's demographic structure has changed. This is largely because of the rapid increase in the number of immigrants, but also because of the growth of the urban population and the consequent worsening of the crisis in rural areas. An additional factor is the change in family structure with the traditional nuclear type, no longer the dominant mode. The labour market has also changed, with an inexorable climb in the number of short-term contracts ("MacJobs") and the loss of thousands of jobs in the industrial sector. Formerly concentrated urban populations have given way to forms of dispersed growth, or "urban sprawl", favoured by laxer town-planning controls in municipalities on the edge of the main city areas. Patterns of consumption have varied as well, as have the retail trade centres. For the moment at least, corner shops have been abandoned in favour of shopping centres of avant-garde design. These new centres have replicated those found in other countries and have become the new meeting points for socialising. In short, Spain has definitively gone from being "a different sort of country" to becoming a faithful reflection of its richer European neighbours. To some extent, this can be regarded as evidence of the process of globalisation, which has affected many European countries in recent decades.

However not all has been changed and evolutionised. Among the constants, for instance, has been the country's dependence upon foreign tourism. The slogan used in the

*Address correspondence to this author at the Department of Geography, University of Castilla-La Mancha, Spain; Tel: 925-268800; Fax: 924268814; E-mail: luisalfonso.escudero@uclm.es previous paragraph, "Spain is different", was adopted from the 1960s onwards to attract the attention of hundreds of thousands of Europeans, mostly from the United Kingdom, Germany, and France. Keeping the balance of external trade healthy only by means of the direct and indirect income derived from tourism ought to have become a thing of the past. However, more than ever before Spain depends on the tourists continuing to arrive on its beaches, even at the cost of turning the Mediterranean coastline into a continuous strip of concrete. If necessary, a blind eye will be turned while building firms covering thousands of hectares of farmland with tarmac, with a view to increase what is paradoxically called residential tourism. Another feature that has not changed is the powerful attraction of Madrid. Decades ago, when young inhabitants of small inland towns or cities decided to look for work elsewhere they had just two options. One was to contact a former neighbour or a relation who had emigrated to Germany, the Netherlands or Switzerland and be prepared to cross the frontier. The other was to head for Madrid, where they were sure to find some form of employment. Despite what is said by all the theories about urban decentralisation, every road and rail route leading to the capital of Spain is clogged each Sunday by a large and growing flood of people who are making their way back from a weekend spent in their home towns so as to be at their places of work punctually first thing on Monday morning. Finally, one other thing that has not changed is the rhythm of life in many of Spain's medium-sized cities. A stroll through their streets is a journey back to the past. Of course, the built-up areas have grown, large amounts have been invested in refurbishing the historical town centres, new shopping malls have been opened and more and more people can be heard to have foreign accents, but in these cities Spain is still different. This claim can be substantiated easily if after a few days' stay in any of the larger Spanish cities or on the Mediterranean coast, a visit is made to a city 
such as Segovia, Cuenca, León, Palencia, Huesca, Jaén or Toledo. A particularly striking example is to be found close to Madrid, in the so-called River Henares corridor. On exiting the capital along the A2 motorway in the direction of Barcelona, the traveller first goes through a very heavily industrialised area, dynamic and continuously changing, but only a few kilometres farther on entering the city of Guadalajara where the hectic pace of the nation's capital slows down dramatically.

Studies published on Spanish cities of medium size have become quite frequent in recent years, whether monographic research works on specific towns [1-3] or papers analysing their evolution in general [4-6]. Similarly, recent research into other European medium-sized cities that has appeared in specialist journals has either analysed specific national examples [7-10] or compared different case studies on a continent-wide scale [11-13]. In the majority of these works, it is argued that the future of cities of medium size must be based on the implementation of a multi-centred land-use model for socio-economic development, taking into account factors such as environmental sustainability, territorial balance or horizontal partnership networks linking all the agents involved, taking it for granted that the previous model for growth in large metropolitan areas is now outdated. The data that will be analysed in this paper questions claims of this nature.

It was commented above that some things have not changed in Spain and that among them is the pace of life in certain medium-sized cities. This sentence ceases to be just an anecdotal impression and is shown to be a verifiable fact in the course of this paper. The objective being pursued in this research was to determine to what extent the polycentric development strategies emanating from Brussels and also from various Spanish Autonomous Communities had any repercussion on the specific dynamics of cities of medium size. If land-use policies, strategic plans, networks set up, specific projects, and all the other measures adopted to revitalise these urban centres have been successful, there ought to be a massive resurgence in the intermediate range of urban settlements. If the contrary is true, it could be argued either that the investments made have not been sufficient to reverse the trends, or that the factors boosting the dynamic tendency towards metropolitan growth are even more powerful in their effects.

\section{POLYCENTRICISM AS A EUROPEAN TERRITORIAL STRATEGY}

Land is becoming vitally important, not only for those who work with it, but also for the much wider society and its institutions. In Spain, this importance is founded on the ever clearer need for adequate regulation in the face of uncontrolled growth and excessive use of land in processes such as the urbanisation of coastal areas or the extension of urban peripheries. Some form of land recovery is, thus, being suggested as a direction to be taken by regional policies in view of the necessity of planning correctly for the future.

It was in this context that the European Union approved in 1999, with a target date of 2007, its European land-use strategy, known as the European Spatial Development Perspective. This strategy was a new Community agenda for land use that coincided with renewal of the framework of regulations in Spain (official Plans for Land Use, a new Land Law, and others). It falls within a new land culture, in which the European space, and, hence Spain, is to be defined in an alternative territorial model: polycentric, referring to scales of proximity and requiring a partnership principle in order to set up the networks of agents needed to achieve the development [14].

The ESDP European territorial strategy, the impact of which is fundamental for the regions of Europe, lays down a perspective for land use with the idea that it will be applied by the European Community, the member states, and those responsible for policies at regional and local levels [15]. It has three principal thrusts: development of a balanced and polycentric urban system and a new urban-rural relationship; securing parity of access to infrastructure and knowledge; and sustainable development, prudent management, and protection of nature and cultural heritage. The ESDP later led to the creation of the ESPON organisation (European Spatial Planning Observation Network), an initiative of the European Union, financed by the INTERREG III programme. In this, both technical experts and politicians participate, with the objective of setting up a European network for research, diffusion of ideas and debate on planning in Europe. In the land-use regulations observed by ESPON, the proposals for application of the ESDP, particularly the idea of polycentricism, are included. For medium-sized cities, this concept, multi-centres, is fundamental in several ways. It can act as a planning tool, as a form of urban structure, as an objective in socio-economic policy, and even as a promotional image. Medium-sized cities are seen as the pillars of poly-centralism in urban regions [9]. In reality, the concept of polycentralism is not new, since many variants of it have been put forward and are to be found in the literature of town-planning in the twentieth century. However, the novelty is its growing popularity among those responsible for regional planning and politicians throughout Europe [16]. Such development along multi-centred lines can be found on three main levels:

- $\quad$ At European Union level, there is more emphasis on a dispersed development of dynamic growth centres. This contrasts with the current situation, in which economic activity tends to be concentrated in central regions, turning other areas into peripheries. In fact, there are a number of networks of medium-sized European cities in operation, seeking co-operation to achieve dynamism and multi-centred development. These include: Eurocities, the Co-operation Network of European Medium-Sized Cities, the Urban Network of Representatives, the Medium-Sized Cities Network or Eurotowns, the Fédération des Maires des Villes Moyennes [Federation of Mayors of Medium-Sized Towns], the Red C-6 [the six-city C-6 Network], Mecine or Medium-Sized Cities Network Europe, Capture or the Knowledge Economy Network, and a number of others.

- At a regional level, in those territories where there are a number of inter-connected urban centres rather than one dominant centre, this new policy can be applied. Land-use strategies in the majority of the Spanish 
Autonomous Communities currently strive to strengthen just such a regional polycentricism.

- At an intra-city level, either a single city or a single multi-centred urban area comprising a principal centre and a series of sub-centres. These concentrations are characterised by a high density, both of population and of jobs. Given this range of urban growth, it is possible to envisage polycentricism within an urban region.

Of the three levels just indicated, current land-use strategies, in common with European, national, and regional investments, are concentrating mostly on the inter-city or regional scale, involving the formation of Polycentric Urban Regions or PURs [16]. A PUR is defined as a region with three or more historically and politically separated cities, that have little hierarchical ranking, but are in reasonable proximity and enjoy functional interconnections [17]. Cities of intermediate size are participating actively in this reform of land-use regulations, which aim to construct a more cohesive and balanced area from a social and spatial point of view, and they are doing so by concentrating on innovatory processes to create Functional Urban Areas, or FUAs [18]. Thus, they are shaping their territorial development with an eye to factors deriving from economic competitiveness, learning and knowledge, social welfare and cohesion, environmental sustainability and participation and governance. To this end, it is essential for there to be local agents involved in initiatives, for specific resources to be available, for production to be organised around networks of enterprises and for institutional organisation to be centred on co-operation. All of these are key elements for progress and development in this type of cities.

Strategic planning and co-operation between these medium-sized towns would be the main points for action. Hence, the integration of large multi-centred urban regions demands an individual effort from each city involved and co-operation from many investors in both the public and the private sectors. Responsibility for carrying out policies of polycentricism at this level falls to the authorities charged with national planning and to the cities and regions themselves.

In this way, the process of political decentralisation that has taken place in Spain since the early 1980s has made it possible for the basic elements for guaranteeing cohesion and for strategic land-use planning to be nowadays in the hands of the regional parliaments and governments. However, they are not so far known how, or not been able for other reasons, to take full advantage of this opportunity. The end result, apart from very specific exceptions like the territorial strategy of Navarre, has been a worrying level of segmentation in public policies and fragmentation of the institutional map, which in this context makes any attempt to overcome existing institutional complexity and weakness [20]. This is a stumbling block to the consolidation of a changed orientation in public policy that might incorporate new elements into its discourse, affecting both the content and priorities of policies and the forms and methods of governing territory [19]. Of course, polycentricism requires the adoption of political decisions on a scale different from the local (regional, autonomous community, state or interstate). Here, it encounters the problem of how far local autonomy can exercise competence and authority over town and country planning, as is established legally by the current Land Law in Spain. There is, likewise a serious question mark over budgets, as the investments made to achieve polycentricism are very demanding.

\section{THE OVER ALL DEVELOPMENT INDEX (ODI) FOR MEDIUM-SIZED SPANISH CITIES}

To study recent changes and the current situation in medium-sized cities in Spain, it was decided to establish an overall compound index, which in association with various sub-indices and intermediate operations would bring together in the form of a final measure; the most significant questions experienced by the country in the last ten years. Thus, the higher the index for a given city, the greater its degree of integration into the dynamics of socio-economic growth, while the lower the index, the less in tune the city appeared to be with the ongoing trends of development.

The objective of the analysis was to assess the degree of success of the policies and strategies for multi-centred development, as opposed to the model of metropolitan growth and dispersed urban development along privileged axes. Thus, the study was restricted to medium-sized Spanish cities on the mainland, the Balearic, and Canary Islands being disregarded as special cases. To define quantitatively what was to be understood as a medium-sized city, the precedent of other studies on this intermediate size of settlement was followed, setting population limits between 50,000 and 250,000 inhabitants. This scale is well suited to a Spanish context, although strict application of these two thresholds would leave out some examples that might be considered to fall within the qualitative definition of a city of medium size, being either too small (Teruel, Huesca or Soria) or too big (Vigo, Valladolid or Cordova [Córdoba]). Moreover, this total figure takes into account only the population of the central municipality, despite the fact that in some cases the city extends out into land lying within neighbouring municipalities. Thus, the population figure used to draw up the initial list of medium-sized cities is the one included in the Municipal Register of Inhabitants on $1^{\text {st }}$ January 2006. In this way, 112 cities were selected exclusively by reason of their official population, running from the 50,298 inhabitants of Benalmádena in the Province of Malaga [Málaga] to the 248,150 of L'Hospitalet de Llobregat in the greater Barcelona area. Adding together the populations of all the settlements concerned gave a total of $11,925,155$, approximately $26.7 \%$ of the population registered that year for the whole of Spain.

The medium-sized cities that emerged were split into eight types. Three categories were linked to the metropolitan areas of Madrid, Barcelona, and the other metropolitan urban regions. Another two covered inland and coastal provincial capitals, then came medium-sized coastal cities with principally tourist and industrial functions, and finally other inland cities. Table 1 shows the different, absolute, and relative distributions of the 112 medium-sized Spanish cities. Roughly half of their population, out of the nearly 12 million total, lives inland $(6,166,164)$, the other half on the coast $(5,758,991)$. With regard to totals, inland provincial capitals are the biggest group, with 26 cities, followed by those 
within the two metropolitan areas of Barcelona and Madrid, at 17 and 16, respectively (Fig. 1).

Table 1. Types and Population of Medium-Sized Cities

\begin{tabular}{|c|c|c|c|c|}
\hline & $\begin{array}{c}\text { Greater } \\
\text { Madrid }\end{array}$ & $\begin{array}{c}\text { Greater } \\
\text { Barcelona }\end{array}$ & $\begin{array}{c}\text { Other } \\
\text { Metropolitan } \\
\text { Areas }\end{array}$ & $\begin{array}{c}\text { Coastal } \\
\text { Tourist } \\
\text { Cities }\end{array}$ \\
\hline \hline Number & 16 & 17 & 7 & 10 \\
\hline Population & $1,889,835$ & $1,831,611$ & 547,019 & 724,377 \\
\hline \% Population & 15.85 & 15.36 & 4.59 & 6.07 \\
\hline
\end{tabular}

\begin{tabular}{|c|c|c|c|c|}
\hline & $\begin{array}{c}\text { Coastal } \\
\text { Industrial } \\
\text { Cities }\end{array}$ & $\begin{array}{c}\text { Coastal } \\
\text { Provincial } \\
\text { Capitals }\end{array}$ & $\begin{array}{c}\text { Inland } \\
\text { Provincial } \\
\text { Capitals }\end{array}$ & $\begin{array}{c}\text { Other } \\
\text { Inland } \\
\text { Cities }\end{array}$ \\
\hline \hline Number & 15 & 9 & 26 & 12 \\
\hline Population & $1,381,095$ & $1,454,551$ & $2,954,566$ & $1,142,101$ \\
\hline$\%$ Population & 11.58 & 12.20 & 24.78 & 9.58 \\
\hline
\end{tabular}

The ODI for the medium-sized cities was obtained by adding together five more limited sub-indices. The first two of these were demographic measures, the third concerned to employment, the fourth related to shopping centres and the fifth concerned to house ownership.

Sub-index 1 is simply the average annual demographic growth for the last ten years (1996 to 2006). The highest figure corresponded to the tourist locality of Torrevieja in
Alicante Province, with $15.57 \%$ annual growth, followed closely by Rivas Vaciamadrid (a satellite town intended to take Madrid overspill: its name could be translated literally as "Riverbanks Empty Madrid") at 13.63\%. At the opposite end of the scale came Cadiz [Cádiz], which lost population, having an annualised rate of $-1.03 \%$, and Ferrol with $-0.8 \%$.

Sub-index 2 represented the new demographic vitality arising from the growing flows of immigrants being received into today's Spain $v s$ the unstoppable ageing of local population and was calculated from the ratio between foreign population and inhabitants aged over 65 . In this case, the highest figures were recorded for two towns in the Province of Almería, the tourist spot Roquetas de Mar (3.12\%) and the agro-industrial El Ejido (3.00\%), while, curiously, the lowest values were to be found just a few kilometres away, once again in Cadiz $(0.05 \%)$ and in the nearby Sanlúcar de Barrameda (0.06\%).

The rhythm of growth in employment gave the third subindex, derived from the monthly percentage of variation in the number of contributors paying into Social Security funds during the year 2006, a measure of the dynamics of the active population. In this instance, the city of Gerona [Girona] was leader, with monthly growth of $2.17 \%$, followed by Alcobendas, on the outskirts of Madrid, at $1.18 \%$. Negative figures, showing losses of jobs, were recorded in just three localities, all of them in the Province of Barcelona, Terrassa $(-0.41 \%)$, Rubí $(-0.35 \%)$ and Manresa $(-0.31 \%)$.

The fourth sub-index attempts to show changes in consumer behaviour, by calculating the number of square metres of shopping centres or malls per inhabitant. In this

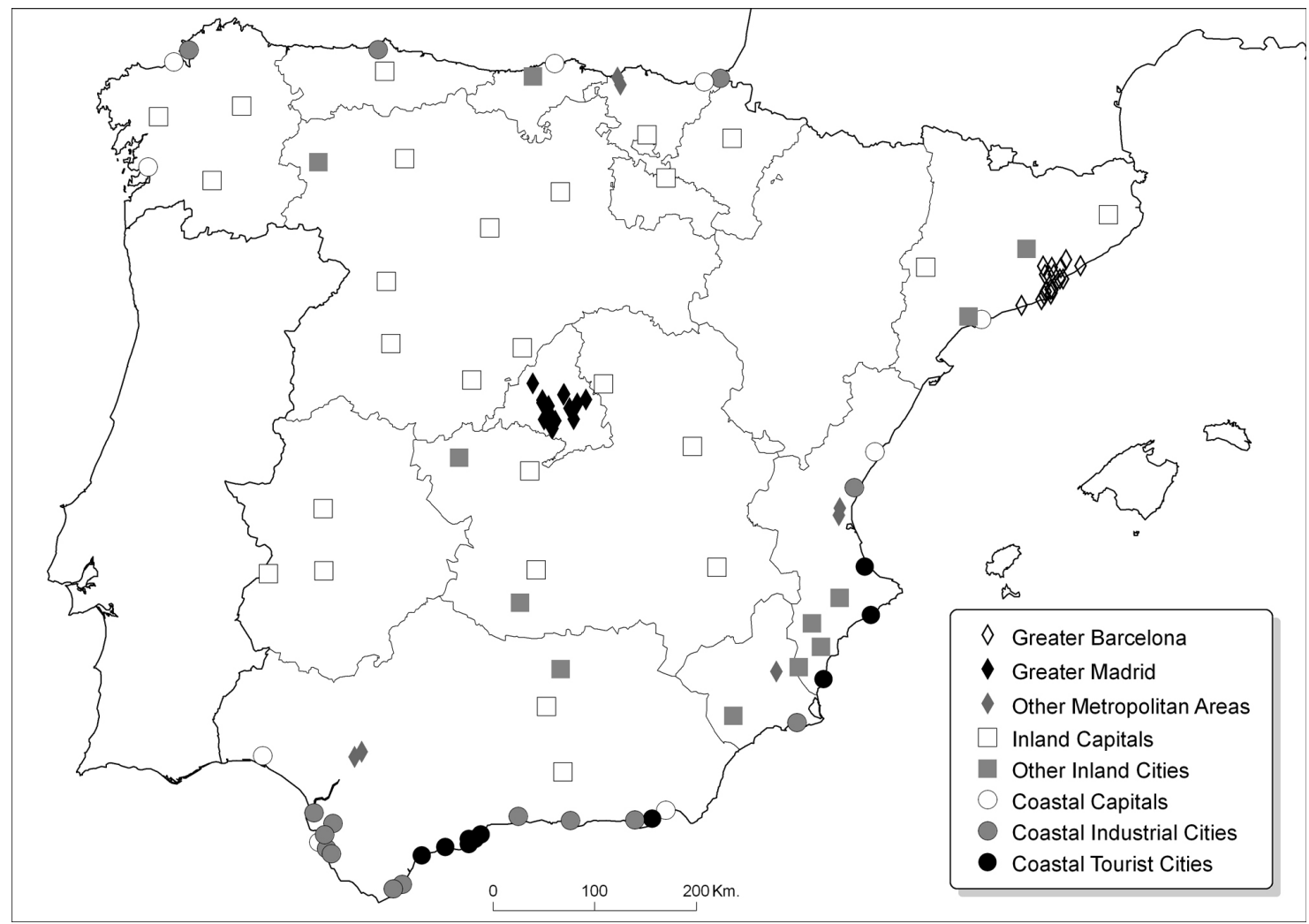

Fig. (1). Location and types of spanish medium-sized cities. 
sub-index, the metropolitan area of Madrid really stood out, since eight of the ten highest figures corresponded to cities lying on the outskirts of Spain's capital, starting with San Sebastián de los Reyes at 1.60 square metres and Alcobendas, with 1.58. In contrast, nine cities as of 2006 had no shopping centre, six of these being in the metropolitan area of Barcelona.

Finally, the fifth and last sub-index represented the percentage of variation during 2005 in the number of house-owners using the data for 2004. On this occasion, the highest value was for Benalmádena $(9.62 \%)$, followed by Orihuela (8.96\%) and Alcalá de Guadaira (6.44\%), this latter place being in the urban region of Seville [Sevilla]. At the tail of the list there were five cities with negative figures, where the number of house-owners in 2005 was smaller than in 2004. The most negative value was recorded for El Prat de Llobregat $(-0.83 \%)$, on the outskirts of Barcelona, followed by Línea de la Concepción (-0.55\%), on Cadiz Bay.

The five sub-indices were selected among other possible indicators to use official and uniform data bases for all the cities that allowed us to evaluate from different perspectives the development of a medium city. Namely through its population growth, demographic dynamism, business vitality, mass consumption behaviour and real estate development. With this selection social, economic and demographic components were integrated in the synthetic index, which are in our point of view what finally defines the position of cities in the urban hierarchy.

The sum of the values for each of these five sub-indices finally yielded the ODI for each city, with results running from the 21.24 of Rivas-Vaciamadrid down to the 0.33 for Cadiz. The appendix lists these final values.

Fig. (2) shows 25 cities scoring the highest index values. Mostly they are cities on tourist parts of the coast (9) and in the metropolitan area of Madrid (8), to which are added two further towns in the greater Barcelona area and two cities on other urban peripheries (those of Murcia and Seville). The other places in this top 25 are two coastal industrial cities, El Ejido and El Puerto de Santa María, and two inland settlements, Orihuela and Ciudad Real.

It is clear that the two principal vectors for growth are located on the coast or on the periphery of the capital city. In reality virtually no polycentricism is reflected here. Ciudad Real, the first example that might be related with this strategy, comes in position 21 , its presence at this rank being justified largely by its sub-index 5 figure, variations in the number of house-owners, with an increase of $4.99 \%$ in 2005 in its figure for proprietors of real estate. However, when it comes to sub-index 1, which reflects annual demographic growth for the period 1996 to 2006, it lay below the average of 112 cities, at only $1.81 \%$. Moreover, the explanation for this rise in the total of house-owners relates to a process of metropolitanisation, being due to the building of a high-speed train $(A V E)$ line that brought Ciudad Real to just fifty minutes of journey time from the centre of Madrid. It is also important to note that this small provincial capital has among the lowest housing prices in Spain. It seems evident that the number of people catching the $A V E$ each day to go to Madrid would be directly linked to this sub-index 5. For its part, Orihuela, the other inland site with a noteworthy

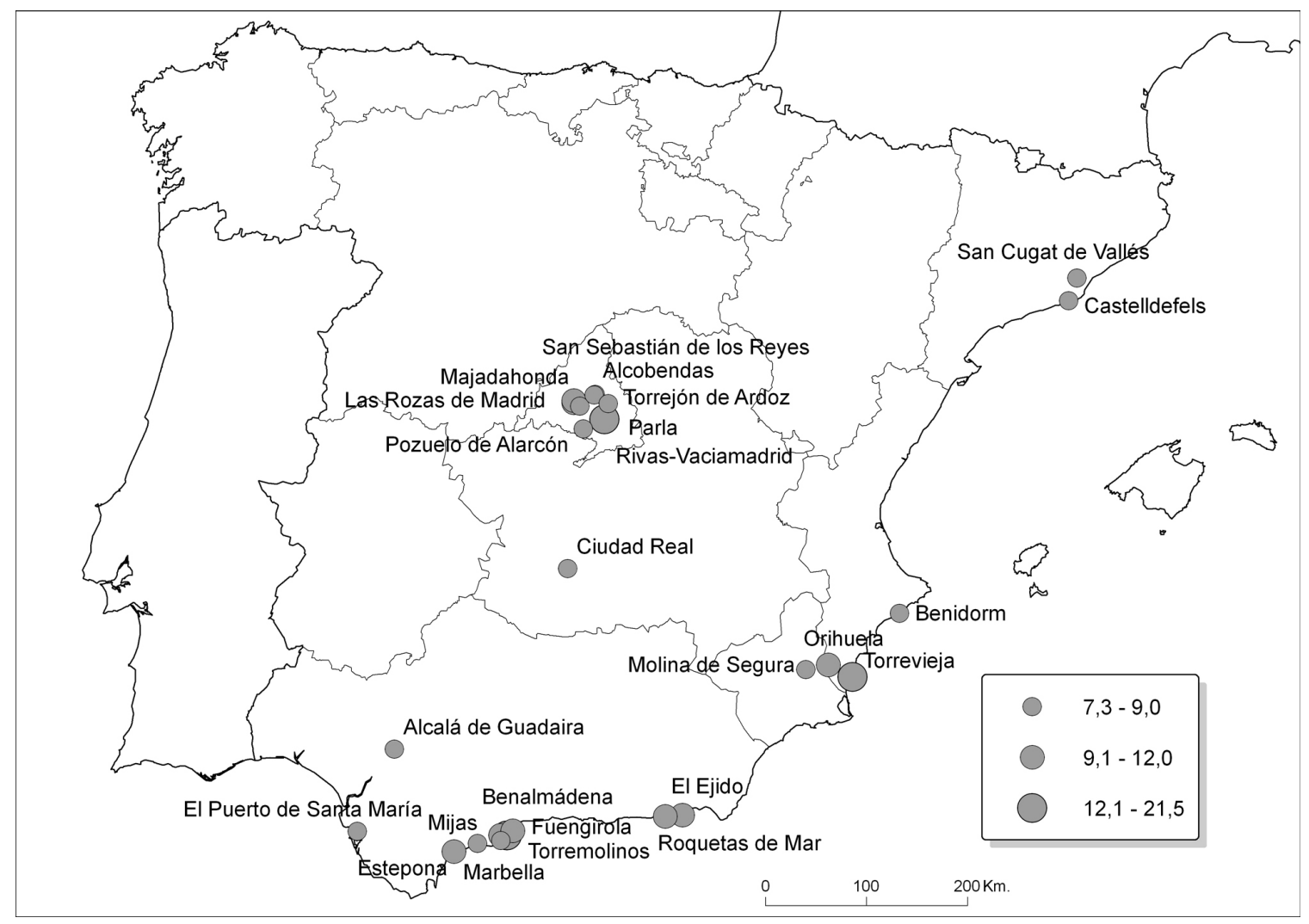

Fig. (2). Location of the 25 medium-sized cities with the highest ODI values 


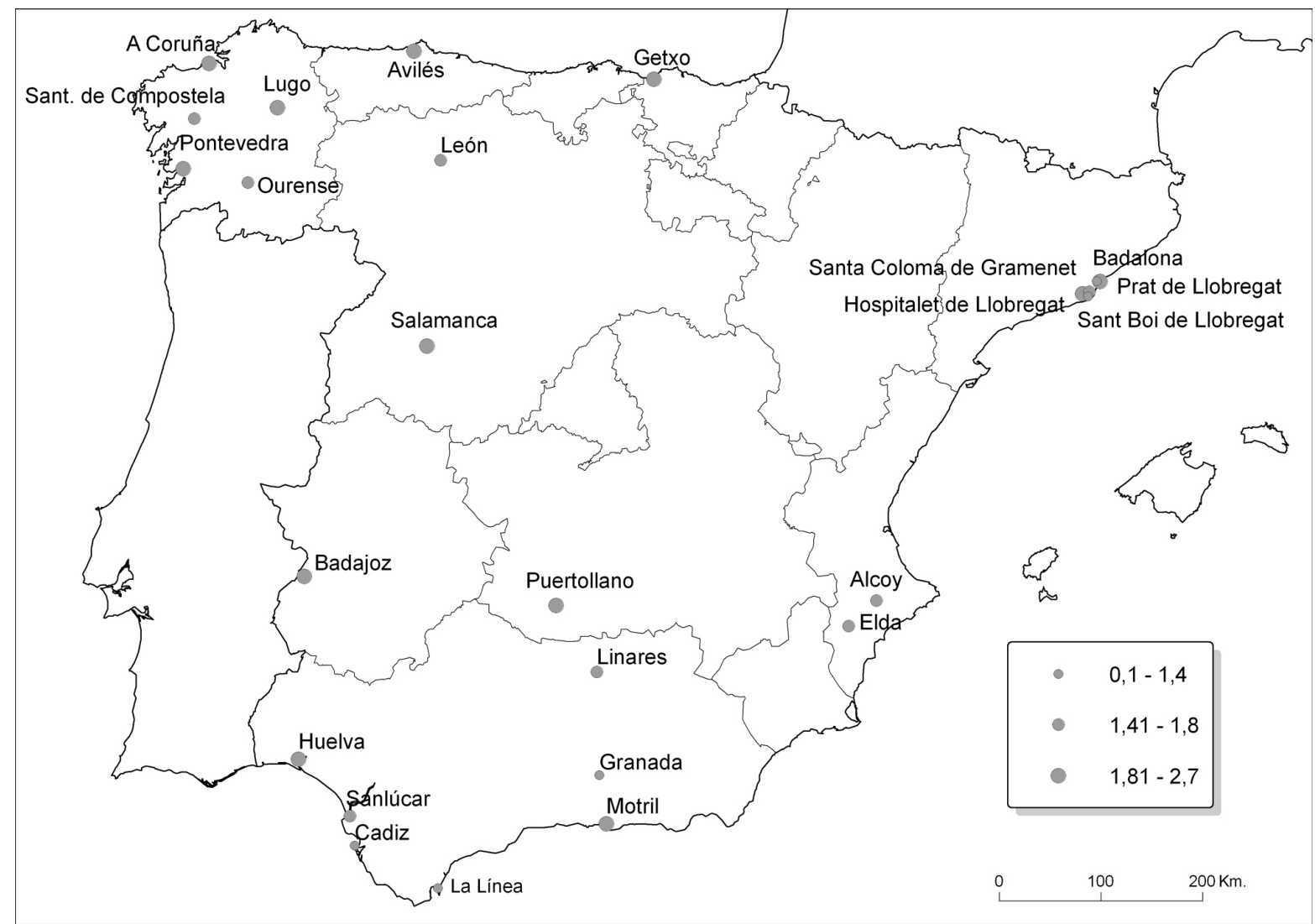

Fig. (3). Location of the 25 medium-sized cities with the lowest ODI values.

position in the ODI ranking, is no more than 28 kilometres from the Mediterranean coast and the boom in construction for tourist purposes has also made itself felt here.

Fig. (3) shows 25 towns with the lowest ODI figures. These are mainly provincial capitals (10) and cities with an industrial past (8), whether situated on the coast (4 and 4, respectively) or inland (6 and 4). Saint James of Compostela [Santiago de Compostela], the administrative capital of Galicia, appears together with these towns, as does Gecho [Getxo], belonging to the industrial periphery of Bilbao, and five cities in the greater Barcelona area, for which all the sub-indices point to serious problems. This situation might be related to the advanced phases in the model for evolution of urban systems of P. Hall [20], as some authors appear to suggest [21], were it not for the fact that the central city here has not continued to lose population, but rather has seen its number of inhabitants increase in the most recent census records.

\section{DEVELOPING AXES AND SPACES VS INTERCONNECTED SETTLEMENTS WITH SYMPTOMS OF STAGNATION}

The statistical index obtained permitted succinct quantitative measurement of a phenomenon, which is economic, social, environmental, and territorial in nature. In this way, the key features of medium-sized cities in present-day Spain could be grasped. The aim was to identify the real trends in growth, which are the genuine results of the policies for multi-centred development, encouraged by the European land-use strategy, and followed at a central government but especially at regional (Autonomous Community) level in the Kingdom of Spain.

Analysis of this ODI (Fig. 4) will now concentrate on the eight types that it has proved possible to establish among Spanish medium-sized cities. In this case, since the number of cities varies from category to category, the figure applied will not be a total, but an indicator based on the average. Values for this range from 12.32 for coastal tourist cities to 3.26 for coastal provincial capitals. The graph shows that there is considerable variation between the various urban types of medium-sized settlements in Spain.

Thus, the first group of cities to stand out are those forming the coastal tourist category, with an average well above all the rest. This set of towns are characteristic of a type of urban development that is highly concentrated on limited sections of the Spanish coast, principally in the Provinces of Alicante, of Almería, and above all of Malaga, where six of the cities with high indices lie. They show growth precisely of the kind that the new land-use strategies are intended to combat, since it is based on using up large amounts of land in an area that is already densely developed; the tourist zones of the Spanish coast. However, the private market for properties and the economic and demographic dynamism of these coastal tourist cities are still running at a higher pace than the new polycentric measures. This feature of urban change in Spain is reflected in the present study.

The next type to note in terms of the index comprises the towns forming part of the greater Madrid area or Madrid metropolitan area, with an average score of 7.98. In fact, this figure would be even higher if there were not a detectable 


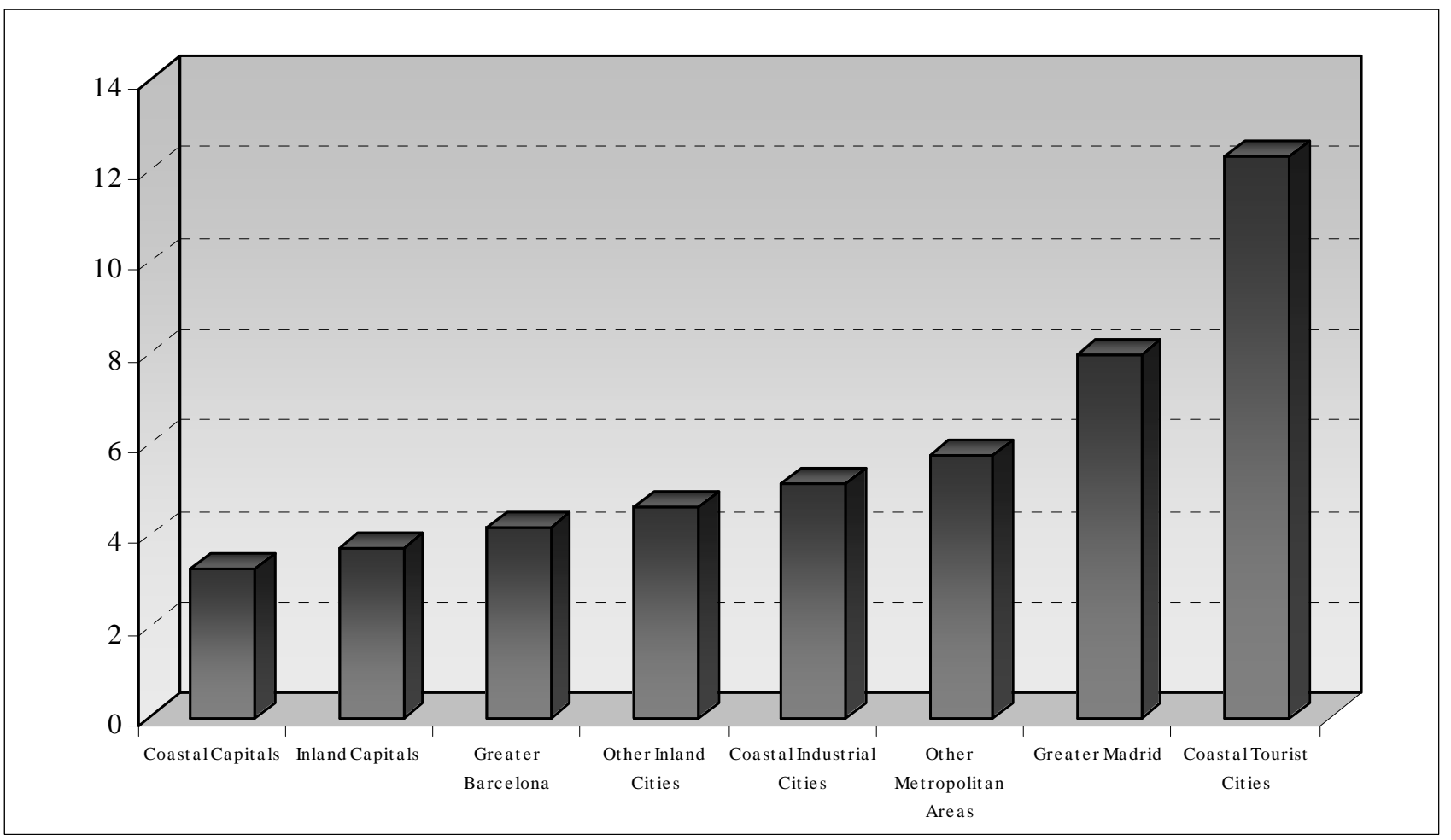

Fig. (4). ODI values for Spanish medium-sized cities. (source: own compilation).

differentiation among these cities into two large groups. One of these groups is currently experiencing strong growth, with an index of more than seven: Rivas, Majadahonda, Las Rozas, San Sebastián de los Reyes, Pozuelo de Alarcón, Alcobendas, Torrejón de Ardoz, Parla and Collado-Villalba. The other suggests more of a consolidation phase, having values under seven: Alcalá, Alcorcón, Coslada, Leganés, Fuenlabrada and Móstoles, these being the most heavily populated parts of the greater Madrid area. This doubtless goes to confirm that in Spain there is still a strong trend towards metropolitanisation in the country's principal urban area. Nevertheless, as was seen above, polycentricism can also be understood as the proliferation of sub-centres within metropolitan areas. This is the process taking place in Madrid, as shown by all the economic indices. In this case, the role of medium-sized cities fits in with multi-centred regional development. In other words, as against the concentration of a metropolitan area there is a spreading of more extensive and dispersed regional urban networks. The ESDP and many Autonomous Communities have sought this outcome. However, after the demands of tourism for urban development, a metropolitan dynamic in Madrid is the second great process of development of medium-sized settlements in Spain.

The other metropolitan area, greater Barcelona, presents a lower overall index, at an average of 4.15. This is still, as will be seen below, higher than those for inland provincial capitals and coastal provincial capitals, although just two towns, Sant Cugat del Vallès and Castelldefells, reach a figure higher than seven. There is less dynamism visible here in the process of metropolitanisation of greater Barcelona. The cause, as in the most heavily populated towns in the Madrid area, is the consolidation of a process that appears to be reaching a plateau. The sub-centres in the Barcelona metropolitan area have reached such a high level of development, especially from the demographic and economic viewpoint, and their urban density is now so great that the slowing down is not abandonment or deficit, but evidence for the end of the cycle of fastest growth.

The types termed other metropolitan areas, coastal industrial and other inland are made up of urban areas with very different characteristics. However, their final averages are quite similar, being 5.75, 5.11, and 4.6, respectively. An expanded version of this paper might aid in understanding structures and dynamics, which are more local than general in these cities. Nevertheless, the overall index allows several interesting conclusions to be reached. For instance, the cities forming the other metropolitan area periphery group once again point up the importance of the dynamics of metropolitanisation in Spain. Hence, apart from the two largest urban areas, the group of Spanish medium-sized cities offer other, smaller, peripheral zones, with different rhythms. The Bilbao area seems to have reached a plateau (Baracaldo [Barakaldo] and yields a figure of 2.93, while Getxo has 2.34) and the Valencia area would appear to be entering a phase of stagnation (Torrent scores 4.08 and Paterna 6.09). However, the metropolitan areas around Seville stand out in Spain by reason of their rapid growth rates (Alcalá de Guadaira, at 9.05), as do those around Murcia (Molina de Segura, with 9.08). It is with respect to the types labelled coastal industrial and other inland that it is hardest to generalise, since individual cases are so very different (for example, in the second category there is a wide range between Orihuela, in Alicante Province, with a figure of 15.94, and Alcoy, in the same Province, with 1.6). Nonetheless, the highest growth rates, for example in El 
Ejido (11.95), point to well-chosen economic dynamics that have boosted demographic and urban growth. This is economic development more related to taking good advantage of given local strengths, for example the good conditions for intensive greenhouse agriculture in El Ejido than with any institutional strategy for multi-centredness.

Finally, the medium-sized cities, which because of their functions and location ought most to take on board strategies for multi-centred development, inland provincial capitals and coastal provincial capitals, are those with the lowest averages for ODI among all the categories established: 3.73 for those inland and 3.26 for those on the coast. Of these two groups, only Ciudad Real, at 8.06, and Gerona, at 7.13, has an index above seven. Basically, their particular development can be related just as easily to their increasing links with the nearby metropolitan areas of Madrid and Barcelona, respectively, as to polycentricism. In contrast, there are many towns with an index below three: Pontevedra, Huelva, Corunna [A Coruña], Cadiz, Segovia, Badajoz, Salamanca, Granada, and others. Efforts to strengthen the leading role of such medium-sized cities within multi-centred urban regions, as emerges from this study, give worse results in terms of demographic, economic, and town-planning developments than do the trends towards metropolitanisation, or even more, those related to tourist activity on the eastern and southern coasts. Hence, polycentric regional development has not achieved the same growth rates as those of the organisations of land use that it was intended to outstrip, despite the considerable investments made.

\section{CONCLUSIONS}

The fundamental objective of this paper was to check whether the policies and specific actions developing out of the European land-use strategy, tending to encourage polycentricism, had had repercussions on the recent dynamics of Spanish medium-sized cities. For this purpose, an overall development index (ODI) was created, the results of which allowed certain conclusions. The 112 cities selected on the criterion of the demographic threshold were classified into eight different types, with regard to their location on the coast or inland, and by their main function and administrative category.

In the overall listing for the medium-sized cities and in the analyses for each type individually, both zones stand out by reason of their great dynamism. These are the greater Madrid area and the tourist areas of the Mediterranean coast. It might be supposed from this that all of the coastal areas and the remainder of the metropolitan areas would follow the same positive trend, but this does not actually occur. In fact, the last two positions in the ranking fall to El Prat de Llobregat, in the greater Barcelona area, and Cadiz. In neither of the two cases is this merely a coincidence. The localities situated along Cadiz Bay with the greatest industrial presence, together with other cities on the Mediterranean and Atlantic coasts, show figures well below the average. Other nearby places, even some on the same Bay, come among the first 25 . In most of the cities located on the Mediterranean coast, sub-index 5, which refers to increases in the numbers of people owning real estate, is the fundamental explanatory factor; a logical consequence of the unstoppable speculative development of housing along the coasts of Spain. In the Barcelona metropolitan area, several cities in the industrial belt show very low figures for their ODI, while in a couple of other cases, thanks to strong demographic growth, the indices are much higher. The medium-sized cities in the Bilbao conurbation, likewise, yield low values, as is, in general, the case for all the medium-sized cities situated in the north of Madrid.

The first city in the northern half of Spain to be found in the list, apart from places on the outskirts of Barcelona, is Gerona in position 27, the next being Santander at number 41. This would appear to indicate that there is a process of redistribution of socio-economic development in a north-to-south direction. Similarly to what has happened in the United States, Spain also shows a spatial diffusion of development from the industrial "rust belt" of the north to the "sun belt" of the south.

Cities in the interior are in general those with the lowest ODI figures. These are precisely the places that have shown themselves most interested in associating with other European localities of a similar nature, going for sustainable development, promoting knowledge, protecting their heritage, and improving urban governance. Without a doubt, such measures have improved the quality of life of their inhabitants, but in themselves have had hardly any success in attracting new population and business investments. In the longer term, as communications have improved, this fact has led to a constant increase in mobility. Commuting from home to workplace is no longer limited to travel between the city centre and the outskirts, but now can be from mediumsized cities to metropolitan areas or conurbations.

Thus, in the medium-sized cities, analysed multi-centredness has not triggered the development forecast by European and regional policies, at least not at the level studied here. The cities which have indeed experienced a positive dynamic over the last ten years are those from the next category up, with a population lying between 250,000 and 1,000,0000 inhabitants. For them the balance has been positive in every case: Valencia, Saragossa [Zaragoza], Seville, Bilbao, Cordova, Malaga, Murcia (the high ODI for Molina de Segura within its urban area is worth recalling), Las Palmas in the Canaries [Las Palmas de Gran Canaria], San Sebastian [Donostia], Valladolid, Gijón or Vigo. However, it is a moot point whether one can speak of polycentricism in urban regions with more than 500,000 inhabitants.

In fact, it is possible that the balance sought by the European land-use strategy will not be achieved through a polycentric system governed by a new set of relationships between country and city, but rather through the creation of a second-level network of small metropolitan areas towards which the medium-sized cities in their sphere of influence will increasingly look for their functional linkages. 


\section{APPENDIX}

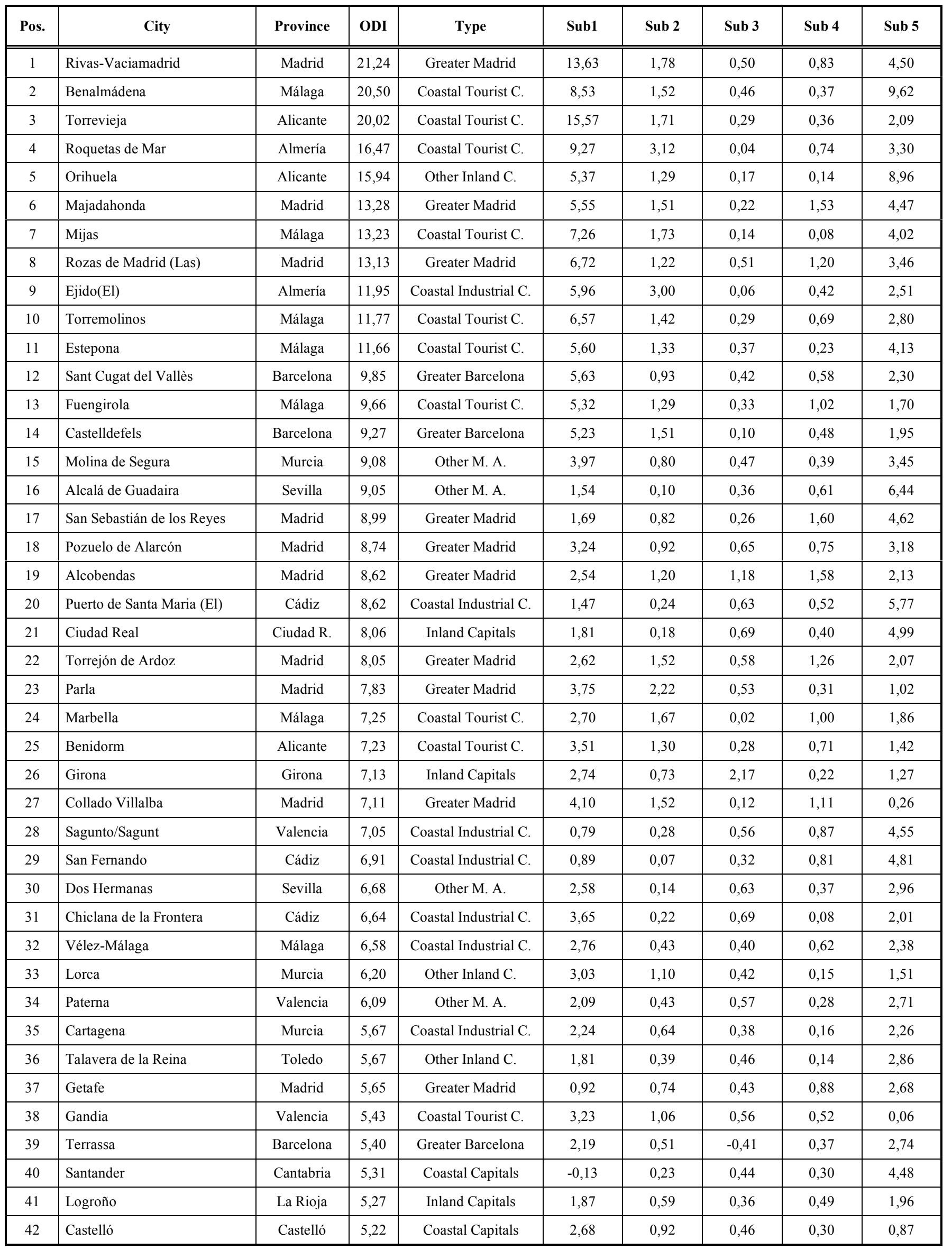


(APPENDIX) contd.....

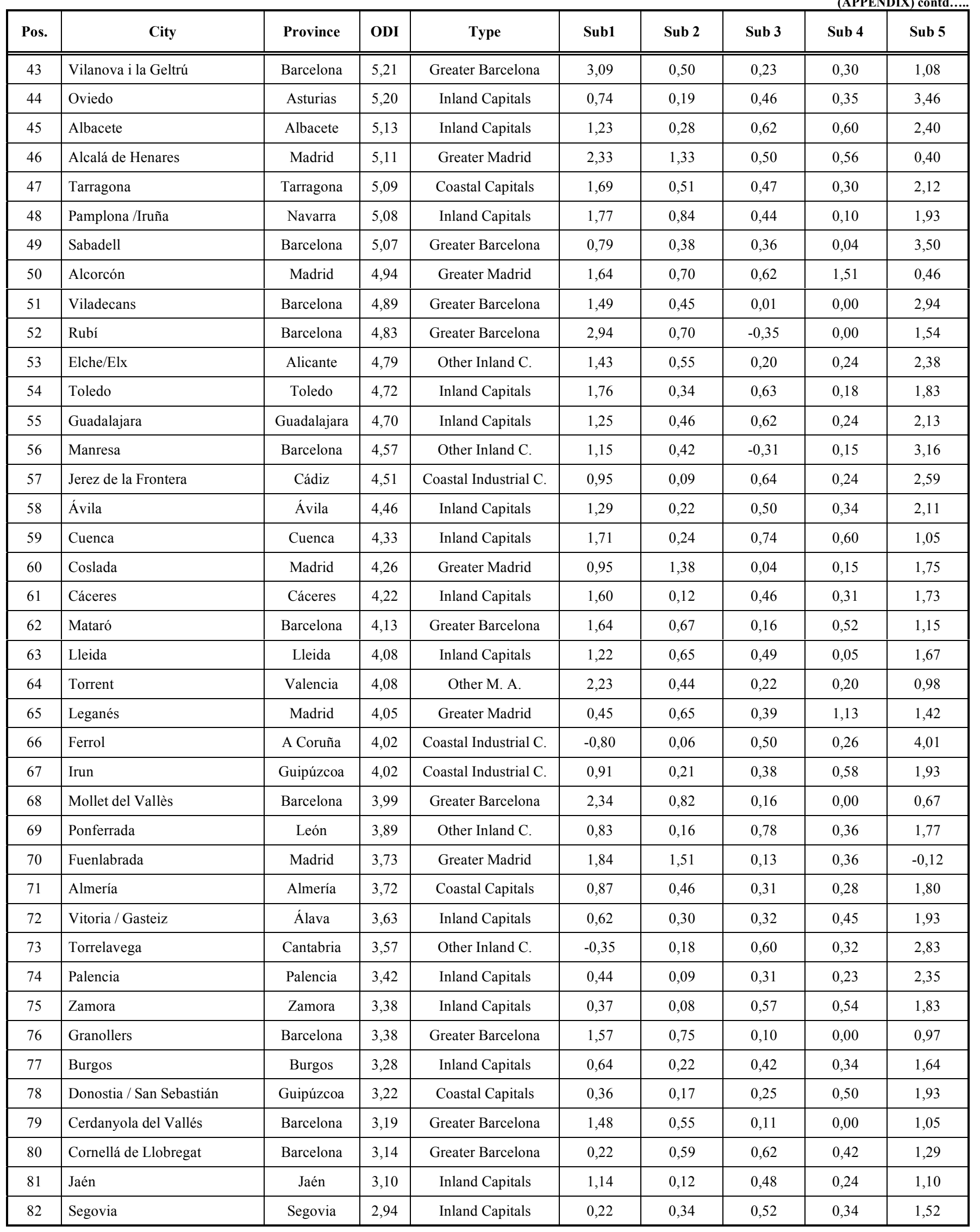


(APPENDIX) contd.....

\begin{tabular}{|c|c|c|c|c|c|c|c|c|c|}
\hline 83 & Barakaldo & Vizcaya & 2,93 & Other M. A. & $-0,48$ & 0,08 & 0,27 & 1,13 & 1,93 \\
\hline 85 & Mérida & Badajoz & 2,85 & Other Inland C. & 0,40 & 0,09 & 0,46 & 0,17 & 1,72 \\
\hline 86 & Algeciras & Cádiz & 2,84 & Coastal Industrial C. & 1,08 & 0,29 & 0,58 & 0,08 & 0,80 \\
\hline 88 & Puertollano & Ciudad R. & 2,72 & Other Inland C. & $-0,06$ & 0,08 & 0,60 & 0,16 & 1,93 \\
\hline 89 & Motril & Granada & 2,63 & Coastal Industrial C. & 1,51 & 0,50 & 0,15 & 0,17 & 0,31 \\
\hline 90 & Sant Boi de Llobregat & Barcelona & 2,46 & Greater Barcelona & 0,43 & 0,38 & 0,14 & 0,52 & 0,99 \\
\hline 91 & Badajoz & Badajoz & 2,46 & Inland Capitals & 1,73 & 0,20 & 0,64 & 0,23 & $-0,34$ \\
\hline 95 & Huelva & Huelva & 2,21 & Coastal Capitals & 0,36 & 0,19 & 0,26 & 0,14 & 1,26 \\
\hline 96 & Badalona & Barcelona & 2,12 & Greater Barcelona & 0,50 & 0,62 & 0,11 & 0,16 & 0,73 \\
\hline 97 & Lugo & Lugo & 2,06 & Inland Capitals & 0,97 & 0,12 & 0,51 & 0,61 & $-0,15$ \\
\hline 98 & Coruña (A) & A Coruña & 2,04 & Coastal Capitals & $-0,02$ & 0,14 & 0,52 & 0,34 & 1,06 \\
\hline 99 & Salamanca & Salamanca & 1,91 & Inland Capitals & 0,03 & 0,18 & 0,58 & 0,19 & 0,93 \\
\hline 100 & Elda & Alicante & 1,79 & Other Inland C. & 0,45 & 0,30 & 0,14 & 0,00 & 0,90 \\
\hline 101 & Santiago de Compostela & A Coruña & 1,77 & Other Inland C. & $-0,02$ & 0,16 & 0,66 & 0,32 & 0,66 \\
\hline 102 & Linares & Jaén & 1,69 & Other Inland C. & 0,20 & 0,10 & 0,26 & 0,15 & 0,98 \\
\hline 108 & Línea de la Concepcion (La) & Cádiz & 1,23 & Coastal Industrial C. & 0,63 & 0,24 & 0,43 & 0,48 & $-0,55$ \\
\hline 109 & Santa Coloma de Gramenet & Barcelona & 1,12 & Greater Barcelona & $-0,33$ & 0,76 & 0,04 & 0,00 & 0,66 \\
\hline 110 & Granada & Granada & 1,05 & Inland Capitals & $-0,31$ & 0,23 & 0,41 & 0,36 & 0,36 \\
\hline 111 & Prat de Llobregat (El) & Barcelona & 0,37 & Greater Barcelona & $-0,03$ & 0,40 & 0,63 & 0,20 & $-0,83$ \\
\hline 112 & Cádiz & Cádiz & 0,33 & Coastal Capitals & $-1,03$ & 0,05 & 0,27 & 0,02 & 1,04 \\
\hline
\end{tabular}

\section{REFERENCES}

[1] Escudero GLA. Una ciudad escondida: exclusión social y marginalidad urbana. Cuad Geogr Univ Granada 2005; 36: 517-26.

[2] Somoza M J. Ourense: La ciudad en el tiempo y el espacio. León: Universidad de León 2002.

[3] Santos Y, Ganges L. Burgos y el ferrocarril. Estudio de Geografía Urbana. Burgos: Dos Soles 2005.

[4] Campesino FAJ, Troitiño VMA, Campos RML. Las ciudades españolas a finales del siglo XX. Cuenca: Age 1995.

[5] Mallarach IJ, Vilagrasa IJ. Los procesos de desconcentración urbana en las ciudades medias españolas. Ería 2002; 57: 57-70.

[6] Sanchez CA, Propin FE. Cambios en la orientación funcional de las ciudades medias del trópico mexicano. Cuad Geogr 2001; 31: 6985.

[7] Hall P, Marshall S, Lowe M. The Changing Urban Hierarchy in England and Wales, 1913-1998. Reg Stud 2001; 35(9): 775-807 [Available from: http://www.informaworld.com/smpp/ title $\sim$ content $=\mathrm{t} 713393953 \sim \mathrm{db}=\mathrm{all} \sim \mathrm{tab}=\mathrm{issueslis} \sim$ branches
[8] Costa E. Ciudades médias: contributos para a sua definição Finisterra. Rev Port Geogr 2002; 37(74): 101-28.

[9] Adam B. Medium-sized cities in urban regions. Eur Plann Stud 2006; 14(4): 547-55.

[10] Riguelle F, Thomas I, Verhetsel A. Measuring urban polycentrism: a European case study and its implications. J Econ Geogr 2007; 7 : 193-215.

[11] Wiberg U. Medium-sized cities and renewal strategies. Pap Reg Sci 1993; 72(2): 135-43.

[12] Pulido N. Globalización y surgimiento de ciudades intermedias en América Latina y en Venezuela. Rev Geogr Venez 2004; 45(1): 91121.

[13] Erickcek GA, Mckinney H. Small cities blues: looking for growth factors in small and medium-sized cities. Econ Dev Q 2006; 20(3): 232-58.

[14] Cañizares RM, Del C. Los cambios y las estrategias territoriales: hacia una correcta ordenación del territorio en Castilla-La Mancha Biblio3W. Revista Bibliográfica de Geografía y Ciencias Sociales 2007; 704. Available from: http://www.ub.es/geocrit/b3w-704.htm 
[15] Faludi A. Las tradiciones de planificación territorial en Europa: su papel en el proceso de la Estrategia Territorial Europea. In: Dasí FJ, González RJ, Eds. Ordenación del territorio y desarrollo territorial. Gijón: Ediciones Trea 2004; pp. 17-44.

[16] Davoudi S. Acerca de la idea del policentrismo en la Estrategia Territorial Europea. In: Dasí FJ, González RJ, Eds. Ordenación del territorio y desarrollo territorial. Gijón: Ediciones Trea 2004; pp. $127-43$.

[17] Comision Europea. Sexto informe periódico sobre la situación y evolución socioeconómica de las regiones en Europa. Luxemburgo: Oficina de Publicaciones Oficiales de las Comunidades Europeas 1999.
[18] Aalbu H. Europa policéntrica: Utopía o posibilidad? In: Dasí FJ, González RJ, Eds. Ordenación del territorio y desarrollo territorial. Gijón: Ediciones Trea 2004; pp. 145-70.

[19] Romero GJ. Gobierno del territorio y políticas públicas en un Estado compuesto. In: Dasí FJ, González RJ, Eds. Ordenación del territorio y desarrollo territorial. Gijón: Ediciones Trea 2004; pp. 215-32.

[20] Hall P. The World cities. London: W \& N 1984.

[21] Boix XG, Castañer VM. Una tipología de áreas urbanas en Cataluña: una revisión del modelo de cohesión. In: López L, Relea C, Somoza J, Eds. La ciudad. Nuevos procesos, nuevas respuestas. León: AGE 2003; pp. 389-97.

(C) Gómez and Medina; Licensee Bentham Open.

This is an open access article licensed under the terms of the Creative Commons Attribution Non-Commercial License (http://creativecommons.org/licenses/by$\mathrm{nc} / 3.0 /$ ) which permits unrestricted, non-commercial use, distribution and reproduction in any medium, provided the work is properly cited. 